\title{
EFFECTS OF CEFAN MELON (CUCUMIS MELO L.) SEED EXTRACTS ON HUMAN ERYTHROCYTE CARBONIC ANHYDRASE I-II ENZYMES
}

\author{
AKKEMIK, E. ${ }^{1,2^{*}}-$ AYBEK, A. ${ }^{1}-$ FELEK, I. $^{1}$ \\ ${ }^{l}$ Department of Food Engineering, Faculty of Engineering, Siirt University, 56100 Siirt, Turkey \\ ${ }^{2}$ Science and Technology Research and Application Center, Siirt University, 56100 Siirt, Turkey \\ *Corresponding author \\ e-mail:eakkemik@siirt.edu.tr; phone: +90-484-223-1224/3020)
}

(Received $11^{\text {th }}$ Jun 2019; accepted $11^{\text {th }}$ Oct 2019)

\begin{abstract}
Carbonic anhydrases (CAs, E.C.4.2.1.1) are an important metalloenzyme family that catalyzes reversible $\mathrm{CO}_{2}$ hydration and $\mathrm{HCO}_{3}{ }^{-}$dehydration in organisms. $\mathrm{CA}$ inhibitors can be used in the treatment of many diseases such as glaucoma, epilepsy, obesity, and cancer. This study aimed to determine the effects of oil and methanol extracts of Cefan melon (Cucumis melo L.) seed (CMS) on CA enzyme activity. While both extracts activated hCA-I isoenzyme, they inhibited hCA-II. In order to determine the active substance causing inhibition or activation in CMS, essential oil content, phenolic substance profile and macro-micronutrient elements were investigated. Dominant fatty acids were identified as linoleic and oleic acid, while the dominant phenolic compound was gallic acid. Besides, it was found that CMS contained high concentrations of $\mathrm{Ca}, \mathrm{K}$ and $\mathrm{Na}$, and was rich in Se. Results demonstrated that essential oil and phenolic compounds in Cefan melon have potential applications as alternative natural products for pharmaceutical industries. In addition, Cefan melon seed has a wide range of applications for food and cosmetic industries based on the research into the fatty acid, phenolic content, and nutrient elements.
\end{abstract}

Keywords: inhibition, activation, fatty acid, phenolic compound, ICP MS

\section{Introduction}

Carbonic anhydrase enzymes (CAs, E.C.4.2.1.1), containing $\mathrm{Zn}^{2+}$ ion as a cofactor in their structure, belonging to the metalloenzyme class, alternately catalyze the hydration of $\mathrm{CO}_{2}$ and dehydration of $\mathrm{HCO}_{3}{ }^{-}$(Supuran, 2008). CAs are encoded by different genes in many families. The class of $\alpha$ CAs which includes high vertebrate organisms contains 16 different isoenzymes. These isoenzymes are tissuespecific and could be seen in different compartments of cells, and they could be used as disease markers (Lehtonen et al., 2004; Cankaya et al., 2007; Uymaz, 2017; Akkemik et al., 2018). CAs are very important in terms of their physiological roles, and besides their role as being $\mathrm{pH}$ regulator enzyme, they are involved in many physiological and pathological events such as calcification, tumor growth and biosynthetic reactions such as urea synthesis, lipogenesis and gluconeogenesis (Scozzafava et al., 2006; Supuran, 2008). Inhibition or activation of these isoenzymes is of paramount importance in many diseases such as glaucoma, epilepsy, gastric, neurological disorders, obesity and cancer (Scozzafava et al., 2006; Supuran, 2008; Aggarwal et al., 2013; Uymaz, 2017). Also, it has been stated that CA activators could be used in the treatment of Alzheimer's disease (AD) (Dilek, 2017; Akkemik et al., 2018).

hCA-I in cell cytosol is involved in the process of $\mathrm{pH}$ homeostasis, respiration and erythroid differentiation (Chegwidden et al., 2000; Picaud et al., 2009; Hassan et al., 
2013). What makes this isoenzyme important is its relationship with some pathological processes such as chronic acidosis, diabetic macular edema, proliferative diabetic retinopathy and vasogenic edema (Chegwidden et al., 2000; Picaud et al., 2009; Hassan et al., 2013). Furthermore, it has been stated that it is a biomarker for many cancer types such as colorectal cancer (Woolley, 1975), non-small cell lung cancer (Dodgson and Forster, 1985) and prostate cancer (Gay et al., 1984). The function of CA II is necessary for bone resorption, osteoclast differentiation and liquid secretion regulation to the ophthalmic anterior chamber. Recent findings suggest that CA II activity functions in connection with several ion carriers, and CA II act as mediators of certain metabolic pathways through providing additional substrates to balance cytosolic $\mathrm{pH}$ of carriers. As a result of these interactions, CA II is involved in the pathogenesis of various diseases such as glaucoma, renal tubular acidosis, cerebral calcification, hypertrophy of cardiomyocytes, growth retardation and osteoporosis (Coleman, 1975; Nishimori et al., 2007; Casey et al., 2009; Torring et al., 2009). Lack of expression and reduced or abnormal expression of these isoenzymes disrupt the balance of the system, which could lead to various diseases. Many synthetic drugs are used to reestablish and sustain this balance. However, synthetic drugs involve expensive synthesis and characterization procedures, and have many side effects. Phytotherapy using natural products has gained importance recently. However, a study examining the effects of melon on CA enzyme activity is not available in the literature.

Melon (Cucumis melo) belongs to the Cucurbitaceae family and is consumed commonly because of its pleasant aroma and flavor. Not only melon fruit but also its peel and seed are consumption material. Moreover, sufficient consumption of melon is beneficial for health. Given the 2017 data of FAO, 75\% of melon production is realized in the Asia continent (FAOSTAT, 2018). While China ranks in the first place in world melon production with 17,082,608 tons, Turkey ranks second with $1,813,422$ tons (FAOSTAT, 2018). There are many melon varieties grown in Turkey. Among the known medical uses of melon are the elimination of kidney stones, treatment of alcohol intoxication and even prevention of heart attacks (Van Wyk and Gericke, 2000; Nyam et al., 2009).

Therefore, In the present study, the effects of the oil and methanol extracts of Cefan melon on the activity of hCA-I and hCA-II isoenzymes were investigated the first time. We hypothesized that oil and methanolic extracts of Cefan melon seeds could exhibit different effects on two isoenzymes in a manner that will keep the system in balance to prevent the onset of diseases. Moreover, in order to determine the active substance causing inhibition or activation in Cefan melon seed, essential oil content, phenolic substance profile, and macro-micronutrient elements were investigated using GC-MS, HPLC, and ICP-MS.

\section{Materials and methods}

\section{Melon seed material}

Cefan melon $(\mathrm{CM})$ is a melon variety growing in TRC3 region covering Siirt, Mardin, Batman and Şırnak in Turkey. Cefan melon was commercially purchased from markets, and maintained in Siirt University, Science and Technology Application and Research Center throughout the study. Dried seeds constituted approximately $6.6 \%$ of Cefan melon. 


\section{Extraction of phenolic compounds and oil}

Extraction of oil was performed based on Malićanin method (Malićanin et al., 2014). This method was modified according to our laboratory conditions. For oil extraction, approximately $30 \mathrm{~g}$ of dried and the ground sample was wrapped in a filter paper and placed in Soxhlet extractor. $400 \mathrm{ml}$ of petroleum ether was added in volumetric flasks which were placed on a hot plate. The condenser was adjusted, and the process was started. The extraction continued for $60 \mathrm{~min}$ at $23^{\circ} \mathrm{C}$. Oil was purified by evaporating petroleum ether of oil mixture obtained at the end of the process in an evaporator (Hei Polphl/Heilbad-hei-vap evaporator). The extraction of phenolic compounds was performed according to method described by Xu et al. (2010). For the preparation of methanol extract, $5 \mathrm{~g}$ granulated melon seed was taken into a volumetric flask. $20 \mathrm{~mL} \mathrm{1:1} \mathrm{distilled} \mathrm{water:} \mathrm{methanol} \mathrm{mixture} \mathrm{was} \mathrm{added,} \mathrm{and} \mathrm{the}$ flask was taken to a shaking water bath (Julabo/SW22) with $200 \mathrm{rpm}$ at $50{ }^{\circ} \mathrm{C}$ for $2 \mathrm{~h}$. After the incubation, centrifugation was performed at 5,000 rpm for $5 \mathrm{~min}$ (Thermo Scientific/Megafuge 16R). The supernatant was taken and used in furthers analyses. All analyses were replicated three times.

\section{In vitro effects of phenolic compounds and oil extracts on human erythrocyte carbonic anhydrase I-II isoenzymes}

Purification of CA I and II isozymes from human erythrocyte was performed in a single step by sepharose-4B-L tyrosine-sulfonamide affinity column. Erythrocyte was hemolyzed with iced pure water at 1:5 (v:v) ratio. The hemolysis solution was centrifuged at $10.000 \times \mathrm{g}$ for $30 \mathrm{~min}$ and the upper layer of hemolysate was collected. The $\mathrm{pH}$ of the hemolysate was adjusted to 8.7 with solid Tris. Then, the hemolysate was applied to the affinity column pre-equilibrated with $25 \mathrm{mM}$ Tris-HCl/0,1 $\mathrm{M} \mathrm{Na}_{2} \mathrm{SO}_{4}(\mathrm{pH}$ 8.7) and the column was washed with $25 \mathrm{mM}$ Tris- $\mathrm{HCl} / 22 \mathrm{mM} \mathrm{Na}_{2} \mathrm{SO}_{4}$ buffer (pH 8.7). The washing process was continued until the absorbance difference of eluate and equilibration buffer reached to 0.05 at $280 \mathrm{~nm}$. Then $1 \mathrm{M} \mathrm{NaCl} / 25 \mathrm{mM} \mathrm{Na} 2 \mathrm{HPO}_{4}(\mathrm{pH}$ 6.3) and $0.1 \mathrm{M} \mathrm{NaCH}_{3} \mathrm{COO} / 0.5 \mathrm{M} \mathrm{NaClO}_{4}(\mathrm{pH}$ : 5.6) buffers were used to elute the hCA-I and hCA-II isoenzymes, respectively. All experiments were carried out at $+4{ }^{\circ} \mathrm{C}$ (Akkemik et al., 2018). The presence of the enzymes in tubes was determined by measuring the absorbance at $280 \mathrm{~nm}$ using elution buffers as blind samples. Then, the enzyme solution was dialyzed against $0.05 \mathrm{M}$ Tris- $\mathrm{SO}_{4}(\mathrm{pH} 7.4)$. The enzyme purity was checked with 3-10\% SDS-PAGE in accordance with Laemmli procedure (Protein Standard; Abcam Inc USA, ab48854) (Laemmli, 1970). Protein determination was performed using the Bradford assay (Bradford, 1976). The esterase activity assay of the hCA isozymes was conducted spectrophotometrically by following the change in absorbance at $348 \mathrm{~nm}$ of 4-nitrophenol produced from 4-nitrophenylacetate by CA catalyzed reaction. The reaction mixture contained $0.05 \mathrm{M}_{\text {Tris- }} \mathrm{SO}_{4}(\mathrm{pH} 7.4), 3 \mathrm{mM}$ pnitrophenol acetate, distilled water and enzyme solution (Verporte et al., 1967; Akkemik, et al., 2018). To determine the inhibitory effect of samples on hCA isoenzymes I and II, esterase activity was measured on samples at five different concentrations. Control cuvette activity was accepted as $100 \%$ in the absence of inhibitor. An Activity \% - [Extract] graph was drawn for each extract. Calculation of $\mathrm{K}_{\mathrm{i}}$ constants was performed using the Cheng-Prusoff equation (Cheng and Prusoff, 1973). VWR UV-6300PC double beam spectrophotometer was used in all spectrophotometric analyses. All analyses were replicated three times. 


\section{Essential oil, phenolic acid and nutrient element composition analyses of Cefan melon}

All content analyses in this study were performed in Siirt University, Science and Technology Application and Research Center.

\section{Analysis of essential oil content by GC-MS}

The fatty acid analysis was performed using a GC-MS Thermo/ISQLT series Gas chromatograph-mass spectroscopy (GC-MS, Thermo Fisher Scientific, the US) based on the method described by Kiliçoğlu (2018) with a slight modification. The GC-MS analysis was conducted with helium gas $(1.2 \mathrm{~mL} / \mathrm{min})$ in the Thermo Scientific TGWAXMS column (60 m- $0.25 \mathrm{~mm}, 0.25 \mu \mathrm{m}$ film thickness). GC furnace temperature was kept at $70{ }^{\circ} \mathrm{C}$ for $6 \mathrm{~min}$, then increased to $230{ }^{\circ} \mathrm{C}$ at a rate of $4{ }^{\circ} \mathrm{C} / \mathrm{min}$ and was finally kept stable for $15 \mathrm{~min}$ at this temperature. Purge flow was adjusted to $5.0 \mathrm{~mL} / \mathrm{min}$. The split flow was adjusted to $6.0 \mathrm{~mL} / \mathrm{min}$ and injection volume was 1 $\mu \mathrm{L}$. Mass spectrometer scan range was adjusted to $\mathrm{m} / \mathrm{z}$ 50-550 atomic mass unit (amu) and screening time was adjusted to $0.2 \mathrm{~s}$. NIST and Wiley GC-MS libraries were used in the determination of the components. The relative percentages of the separated components were calculated from the total ion chromatography through the digital integrator. These analyses were replicated twice.

\section{Analysis of phenolic acid composition by HPLC}

The methanol extract was added to vials using $0.22 \mu \mathrm{m}$ filters. The phenolic composition analysis was performed by a Thermo/DIONEX Ultimate 3000 series high-performance liquid chromatography (HPLC-DAD, Thermo Fisher Scientific, the US) based on the method described by Duran (2014) with a slight modification (Montealegre et al., 2006; Duran, 2014). HPLC was performed with a C-18 Inertsil ODS-3 column $(5 \mu \mathrm{m}$ particle, $4.6 \times 250 \mathrm{~mm}$ ID) which was equipped with a UV detector. The UV detector absorbance was monitored at $280 \mathrm{~nm}$. The mobile phases consisted of solvent A (98: 2 (Water: Formic Acid)) and solvent B (78: 20: 2 (water: Acetonitrile: Formic Acid)). The flow rate was set at $0.75 \mathrm{ml} / \mathrm{min}$, and the column temperature was maintained at $28{ }^{\circ} \mathrm{C}$ throughout the test. Gallic acid (60 ppm), chlorogenic acid (40 ppm), caffeic acid (38 ppm), 4-hydroxybenzoic acid (50 ppm) and vanillic acid (56 ppm) were used as standards (Table 1). The sample injection volume was $20 \mu \mathrm{L}$. The concentrations of phenolic acids in the sample were calculated using standard curves from a plot of peak areas versus levels for a series of standard solutions. The results were multiplied by the dilution factor. These analyses were replicated three times.

Table 1. Analytical parameters for HPLC-DAD analysis

\begin{tabular}{c|c|c|c|c|c}
\hline No & Compounds & UV & Coeff. det \% & Linearity range (ppm) & Slope \\
\hline 1 & Gallic acid & 280 & 99.9039 & $60-6.0$ & 0.8979 \\
2 & Chlorogenic acid & 280 & 99.7478 & $40-4.0$ & 0.6237 \\
3 & Caffeic acid & 280 & 99.9179 & $38-3.8$ & 0.5663 \\
4 & 4-Hydroxy benzoic acid & 280 & 99.9734 & $50-5.0$ & 1.3758 \\
5 & Vanillic acid & 280 & 99.9868 & $56-5.6$ & 0.6652 \\
\hline
\end{tabular}




\section{Determination of nutrient elements by ICP-MS}

For the inductively coupled plasma-mass spectrometry (ICP-MS) technique, 0.2$0.4 \mathrm{~g}$ of Cefan melon seeds were dissolved in $6 \mathrm{~mL}$ of concentrated nitric acid $(65 \%)$ and $2 \mathrm{~mL}$ hydrogen peroxide (30\%), digested in a microwave system (Berghof Microwave Digestion Speedwave MWS-2), and then decomposed $15 \mathrm{~min}$ at $180{ }^{\circ} \mathrm{C}$. After cooling, the preparation was filtered. One milliliter of each filtrate was pipetted into a falcon tube and diluted to $25 \mathrm{~mL}$ with ultrapure water. All samples were then placed in the ICP-MS autosampler unit (Thermo Scientific iCAP Q, 02878R ICP-MS; Plasma power, $1550 \mathrm{~W}$; nebulizer flow, 1.17/min; cooling flow, 14/min; auxiliary flow, $0.8 / \mathrm{min}$ ). These analyses were replicated at least three times (Kuru et al., 2019). The mean values of three measurements were calculated. Calibration solutions were prepared at six different concentrations ranging from 25.00 to $1000.00 \mathrm{ppb}$ using standard solution (ICP Multielement Standard; Sigma Aldrich-1.11355) (Table 2).

\section{Results and discussion}

CAs that are the subject of the present study have roles in $\mathrm{pH}$ regulation in living organisms, and they serve as one of the major buffering systems. Further, they take part in biosynthetic reactions such as urea synthesis, lipogenesis and gluconeogenesis (Scozzafava et al., 2006; Supuran, 2008). However, enzymes of this family are disease markers or disease factors in many physiological and pathological processes such as calcification, tumor formation and Alzheimer's (Scozzafava et al., 2006; Supuran, 2008; Aggarwal, 2013; Akkemik et al., 2018). For this reason, inhibition or activation of these isoenzymes is of high importance in many diseases. For example, currently, CA inhibitors are used in the treatment of various diseases such as glaucoma, epilepsy, gastric and neurological disorders, obesity and cancer (Scozzafava et al., 2006; Supuran, 2008; Aggarwal et al., 2013). There are many studies reporting that activators can be used in AD treatment (Dilek, 2017; Uymaz, 2017; Akkemik et al., 2018). Considering the side effects and high costs of synthetic drugs, demand for natural products has been increasing. Therefore, effects of Cefan melon seed extracts on hCA-I and hCA-II isoenzymes have been investigated in the present study.

The undesirable side effects of synthetic drugs have started to direct many people to natural products. Therefore, research on treatment with natural products has begun to gain popularity. Furthermore, inhibition or activation effects of many plant extracts on carbonic anhydrase enzyme activity have been investigated. In a study the effects of black, green and white, and herbal teas on bovine and human erythrocyte carbonic anhydrase were investigated (Karaçelik, 2018). In a different study, inhibition effects of Artemisia dracunculus L. extracts were investigated against hCA I-II (Yurtvermez, 2016). In another study effects on hCA I-II enzymes activities of Ferula rigidula, Eremurus spectabilis, Rheum ribes and Prangos ferulacea taxa were determined (Sevim, 2018). There are many studies wherein the effects of plant extracts on different enzymes or properties are investigated (Oluba et al., 2007; Bangou, 2011; Sacan, and Yildiz, 2014; El-Hadary and Ramadan, 2019).

Cefan melon was chosen as the subject of the present study because it is a lesser known type of melon, although it is common in a small geographic region. Moreover, it has a sour taste in contrast to other melon species. To our best knowledge, inhibition or activation effects of Cefan melon seed on hCA I-II were determined first time. Two isoenzymes of carbonic anhydrase enzyme were initially purified. For this purpose, sepharose 4B-L-tyrosine-sulfonamide activated with cyanogen bromide affinity column was used. Enzyme purity was checked with SDS-PAGE (Fig. 1). 
Table 2. Standards information used during elemental analysis by ICP-MS (Thermo Scientific iCAP Q)

\begin{tabular}{|c|c|c|c|c|c|}
\hline Element & $\begin{array}{c}\text { Concentration } \\
\text { range (ppb) }\end{array}$ & $\begin{array}{c}\text { Standard curve } \\
\text { equation }\end{array}$ & $\mathbf{R}^{2}$ & $\begin{array}{c}\text { Background equivalent } \\
\text { concentrations (BEC) ppb }\end{array}$ & $\begin{array}{c}\text { Limits of detection } \\
\text { (LOD) ppb }\end{array}$ \\
\hline${ }^{7} \mathrm{Li}$ & $25.00-1000.00$ & $\begin{array}{l}\mathrm{f}(\mathrm{x})=46839.1204 \mathrm{x} \\
\quad+31857.5472\end{array}$ & 0.9992 & 0.680 & 0.0934 \\
\hline${ }^{11} \mathrm{~B}$ & $25.00-1000.00$ & $\begin{array}{l}f(x)=11634.3811 x \\
+62806.0377\end{array}$ & 0.9990 & 5.398 & 0.5031 \\
\hline${ }^{23} \mathrm{Na}$ & $25.00-1000.00$ & $\begin{array}{l}\mathrm{f}(\mathrm{x})=71266.8556 \mathrm{x} \\
\quad+721554.0481\end{array}$ & 0.9994 & 10.125 & 0.6556 \\
\hline${ }^{24} \mathrm{Mg}$ & $25.00-1000.00$ & $\begin{array}{l}f(x)=44262.8717 x \\
\quad+209231.0649\end{array}$ & 0.9992 & 4.727 & 0.8755 \\
\hline${ }^{27} \mathrm{Al}$ & $25.00-1000.00$ & $\begin{array}{l}f(x)=66001.7287 x \\
\quad+281798.3539\end{array}$ & 0.9949 & 4.270 & 0.4715 \\
\hline${ }^{39} \mathrm{~K}$ & $25.00-1000.00$ & $\begin{array}{l}f(x)=83729.4407 x \\
\quad+3887583.5973\end{array}$ & 0.9995 & 46.430 & 0.6893 \\
\hline${ }^{44} \mathrm{Ca}$ & $25.00-1000.00$ & $\begin{array}{c}\mathrm{f}(\mathrm{x})=3999.0021 \mathrm{x} \\
+341506.9113\end{array}$ & 0.9943 & 85.398 & 5.8430 \\
\hline${ }^{52} \mathrm{Cr}$ & $25.00-1000.00$ & $\begin{array}{c}f(x)=87177.3340 x \\
+114923.2662\end{array}$ & 0.9937 & 1.318 & 0.1398 \\
\hline${ }^{55} \mathrm{Mn}$ & $25.00-1000.00$ & $\begin{array}{l}f(x)=122306.5132 x \\
+128449.2444\end{array}$ & 0.9993 & 1.050 & 0.0784 \\
\hline${ }^{57} \mathrm{Fe}$ & $25.00-1000.00$ & $\begin{array}{c}f(x)=2568.9864 x \\
+64650.7997\end{array}$ & 0.9993 & 25.166 & 1.6484 \\
\hline${ }^{59} \mathrm{Co}$ & $25.00-1000.00$ & $\begin{array}{l}f(x)=81035.0866 x \\
\quad+67606.4554\end{array}$ & 0.9988 & 0.834 & 0.0611 \\
\hline${ }^{60} \mathrm{Ni}$ & $25.00-1000.00$ & $\begin{array}{l}f(x)=17630.2008 x \\
\quad+14131.3861\end{array}$ & 0.9996 & 0.802 & 0.0714 \\
\hline${ }^{63} \mathrm{Cu}$ & $25.00-1000.00$ & $\begin{array}{c}f(x)=38817.8017 x \\
+34323.9999\end{array}$ & 0.9996 & 0.884 & 0.0395 \\
\hline${ }^{66} \mathrm{Zn}$ & $25.00-1000.00$ & $\begin{array}{c}f(x)=13461.0977 x \\
+237646.1776\end{array}$ & 0.9962 & 17.654 & 2.1606 \\
\hline${ }^{74} \mathrm{Se}$ & $25.00-1000.00$ & $f(x)=111.5321 x+-$ & 0.9995 & -5.652 & 1.5789 \\
\hline${ }^{75} \mathrm{As}$ & $25.00-1000.00$ & $\begin{array}{c}\mathrm{f}(\mathrm{x})=9679.9289 \mathrm{x} \\
+6428.3363\end{array}$ & 0.9991 & 0.664 & 0.0984 \\
\hline${ }^{76} \mathrm{Se}$ & $25.00-1000.00$ & $\begin{array}{l}f(x)=1263.8109 x \\
\quad+122312.6551\end{array}$ & 0.9995 & 96.781 & 3.2944 \\
\hline${ }^{77} \mathrm{Se}$ & $25.00-1000.00$ & $\begin{array}{c}f(x)=1059.7189 x \\
+1533.4352\end{array}$ & 0.9993 & 1.447 & 0.4007 \\
\hline${ }^{88} \mathrm{Sr}$ & $25.00-1000.00$ & $\begin{array}{l}f(x)=122465.8524 x \\
\quad+102090.6547\end{array}$ & 0.9990 & 0.834 & 0.0172 \\
\hline${ }^{95} \mathrm{Mo}$ & $25.00-1000.00$ & $\begin{array}{l}f(x)=17197.3209 x \\
+10427.7554\end{array}$ & 0.9994 & 0.606 & 0.0367 \\
\hline${ }^{105} \mathrm{Pd}$ & $25.00-1000.00$ & $\begin{array}{c}\mathrm{f}(\mathrm{x})=25.4574 \mathrm{x} \\
+2746.9880\end{array}$ & 0.8436 & 107.905 & 44.2970 \\
\hline${ }^{111} \mathrm{Cd}$ & $25.00-1000.00$ & $\begin{array}{l}f(x)=10842.5299 x \\
\quad+8492.9498\end{array}$ & 0.9993 & 0.783 & 0.0706 \\
\hline${ }^{121} \mathrm{Sb}$ & $25.00-1000.00$ & $\begin{array}{l}f(x)=33942.0002 x \\
\quad+18991.2024\end{array}$ & 0.9987 & 0.560 & 0.0205 \\
\hline${ }^{137} \mathrm{Ba}$ & $25.00-1000.00$ & $\begin{array}{c}f(x)=13617.5973 x \\
+13997.9311\end{array}$ & 0.9989 & 1.028 & 0.2084 \\
\hline${ }^{209} \mathrm{Bi}$ & $25.00-1000.00$ & $\begin{array}{c}f(x)=81754.9691 x \\
+54245.2449\end{array}$ & 0.9992 & 0.664 & 0.1297 \\
\hline
\end{tabular}




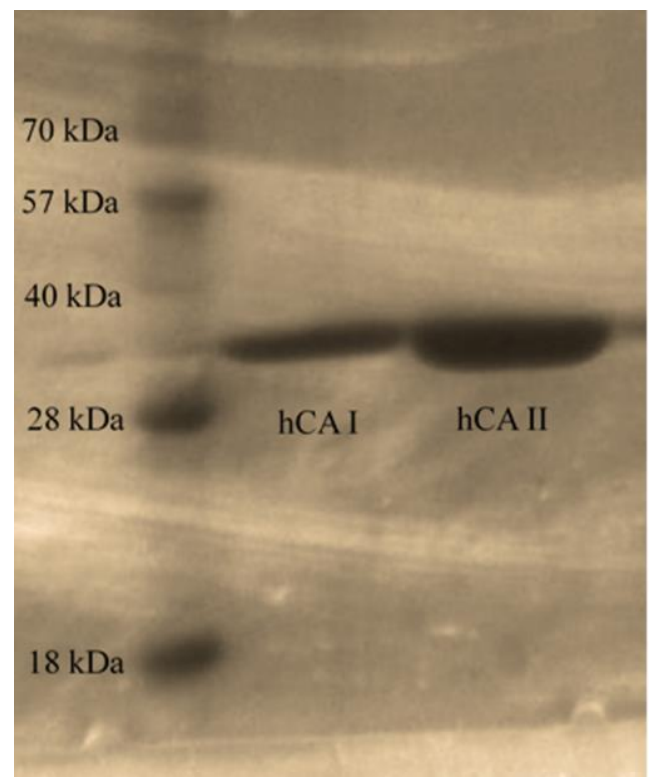

Figure 1. SDS-PAGE bands of hCA I and hCA II

The effects of oil and methanol extracts of melon seed on hCA-I and hCA-II were investigated in vitro conditions (Fig. 2). While both extracts activated hCA-I isoenzyme $\left(\mathrm{AC}_{50} 0.333 \mathrm{ng} / \mathrm{mL}\right.$ and $80.369 \mu \mathrm{g} / \mathrm{mL}$, respectively), they inhibited hCA-II isoenzyme (IC $50.497 \mathrm{ng} / \mathrm{mL}$ and $10.98 \mu \mathrm{g} / \mathrm{mL}$, respectively) (Table 3).

Furthermore, the active substance causing inhibition and activation effect in the Cefan melon seeds was also investigated in the present study. Therefore, the oil content was determined by GC-MS, while phenolic substance content was analyzed using HPLC and nutrient content using ICP-MS.

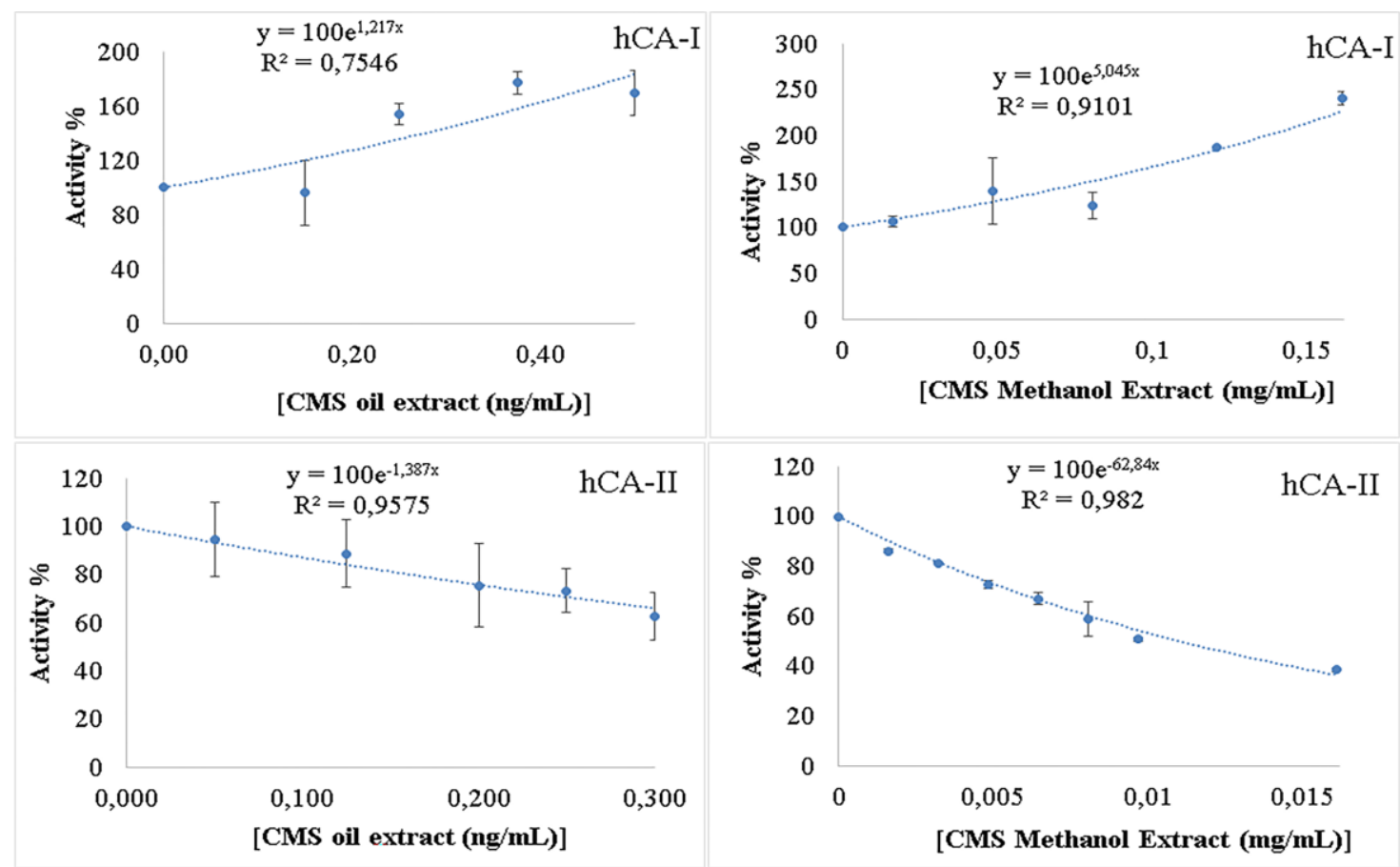

Figure 2. Effects on hCA I and hCA II of melon seed oil and methanol extracts 
Table 3. Effect of extracts on isoenzymes of human carbonic anhydrides I and II

\begin{tabular}{c|c|c|c|c}
\hline Sample & \multicolumn{2}{|c|}{ Melon seed oil extract } & \multicolumn{2}{c}{ Methanol extract } \\
\hline Enzyme & hCA-I & hCA-II & hCA-I & hCA-II \\
\hline $\mathbf{A C}_{\mathbf{5 0}}$ & $0.333(\mathrm{ng} / \mathrm{mL})$ & - & $80.369 \mu \mathrm{g} / \mathrm{mL}$ & - \\
\hline $\mathbf{I C}_{\mathbf{5 0}}$ & - & $0.497 \mathrm{ng} / \mathrm{mL}$ & - & $10.98 \mu \mathrm{g} / \mathrm{mL}$ \\
\hline $\mathbf{R}^{\mathbf{2}}$ & 0.7546 & 0.9575 & 0.9101 & 0.9820 \\
\hline $\mathbf{K}_{\mathbf{i}}$ & - & $0.369 \pm 0.166 \mathrm{ng} / \mathrm{mL}$ & - & $7.25 \pm 0.400 \mu \mathrm{g} / \mathrm{mL}$ \\
\hline
\end{tabular}

In the present study, Cefan melon seed was found to contain approximately $25.00 \pm 0.01 \%$ crude oil. Seeds of different melon cultivars contain about $33.0 \%$ crude oil (Ramakrishna et al., 1970; Teotia and Ramakrishna, 1984; Mello et al., 2001; Kale, 2017). Crude oil extracts obtained were analyzed for fatty acid contents in the GC-MS device. It was found out that the dominant fatty acids in melon seed oil were linoleic and oleic acids (Table 4). Unsaturated fatty acids constituted $67.09 \%$ of total fatty acids in melon seed oil extract.

Table 4. GC-MS data of melon seed oil extract

\begin{tabular}{c|c|c}
\hline Seed oil acids & Retention time (min) & \% \\
\hline Linoleic acid (18:2) & 48.33 & 33.13 \\
Oleic acid (18:1) & 47.13 & 26.24 \\
Palmitic acid (16:0) & 42.03 & 12.24 \\
Stearic acid (18:0) & 46.59 & 7.96 \\
N-decylbenzene (C16 $\left.\mathrm{H}_{26}\right)$ & 35.69 & 7.76 \\
$\gamma$-Linolenic acid (18:3) & 50.84 & 4.48 \\
Dimethylamine, N(Neopentyloxy) & 44.31 & 3.29 \\
$\alpha$-Linolenic acid (18:3) & 58.02 & 3.24 \\
Octadecanoic-D4 acid & 48.91 & 33.13 \\
\hline
\end{tabular}

Inhibitors of hCA-II are used in the treatment of diseases such as glaucoma and epilepsy. Inhibition of hCA-II by very low concentration of both extracts in the present study indicates that both extracts could be efficiently used in the treatments of these diseases. However, an evaluation of $\mathrm{IC}_{50}$ value revealed that oil extract was more effective compared to methanolic extract, possibly because Cefan melon seeds contain a considerable amount of unsaturated fatty acids. Most of these unsaturated fatty acids were essential fatty acids. They are the fatty acids that must be taken through food. Inadequate unsaturated fatty acid intake through food may lead to many diseases such as cardiovascular disease, AD, depression, osteoporosis, and prostate, breast, intestinal and lung cancers (Liperoti et al., 2009; Lee and Park, 2014; Bentsen, 2017). Therefore, Cefan melon seed oil extract may provide a cure for diseases like glaucoma, epilepsy, etc.

The predominant fatty acids in the extracted Kalahari melon seed oil were linoleic (62.2-63.1\%), oleic (16.8-17.1\%), palmitic (11.4-12.4\%), stearic (7.5-8.1\%), linolenic $(0.7-1.2 \%)$, and eicosenoic acids $(0.3 \%)$ (Nyam et al., 2009). Another study mentioned that although the seeds of a different melon variety contained unsaturated fatty acids such as palmitic and stearic acids, the dominant fatty acid was unsaturated ones, 
especially linoleic and oleic acids (Mehra et al., 2015). Similarly, as a result of the analysis conducted in the seed oil of 10 different kinds of melon, it was stated that they contained 57.14-74.66\% linoleic acid, $12.95-28.37 \%$ oleic acid, and 6.98-10.07\% palmitic acid (Kale, 2017). Comparing the data from the present study and results in the literature, we could say that the fatty acids are similar. However, they vary in terms of amount. For example, Cefan melon seed contained relatively less linoleic acid.

An in vitro study was performed to investigate the effect of oil extract of melon seeds on serum lactate dehydrogenase, alanine transaminase, aspartate transaminase and $\gamma$ glutamyl transpeptidase levels in rats. It was reported that activities of the specified enzymes were lower in rats fed with melon seed oil extract (Oluba et al., 2007). Their results demonstrated that melon seed oil extract has a regulatory role in metabolism and this finding supports our results.

The methanolic extract showed an activation effect on hCA-I activity, whereas its effect on hCA-II activity was inhibitory. There was an 8 -fold difference in the concentration range at which methanolic extract was effective on hCA-I and hCA-II. Different effects in different doses of both isoenzymes lead to selective inhibition. This finding showed that the inhibition effect was more pronounced.

In our study, the main phenolic compound in Cefan melon seed was found to be gallic acid. According to the HPLC results, Cefan melon seed contained $247.401 \pm 5.9816$ ppm gallic acid, 50.1811 \pm 8.8379 ppm chlorogenic acid, $3.6850 \pm 1.5866 \mathrm{ppm}$ 4-hydroxybenzoic acid and $2.7173 \pm 1.8528 \mathrm{ppm}$ vanillic acid while caffeic acid was not detected (Fig. 3). In a study where a phenolic analysis was conducted both in peel and seeds of a kind of melon grown in Brazil, it was stated that gallic acid was the dominant phenolic compound in both samples, which also contained catechins, salicylic acid, and eugenol (Rolim, et al., 2018). Furthermore, they also found that the peel extract contained more phenolic acid compared to seeds (Rolim et al., 2018). In a different study, it was stated that gallic acid, caffeic acid, and catechins were dominant phenolic compounds in melon seed extract (Zeb, 2016). In a study where a phenolic analysis was conducted in peel, fruit, and seeds of Cefan melon, it was stated that gallic acid was the dominant phenolic compound in all samples (Özbek, 2019). A comparison of the results from the present study with the data in the literature showed that the content and concentration of the phenolic compounds vary in different varieties grown in different areas of the world, which could be due to climatic conditions (Zeb, 2016; Rolim et al., 2018).

While phenolic compounds were suggested to cause inhibition by interacting (through hydrogen bonding) with water molecules around $\mathrm{Zn}^{2+}$ in the active region of the carbonic anhydrase enzyme (Durdagi et al., 2011), no clear mechanism for the activation was proposed. In our study, the gallic acid was dominant compared to other phenolic compounds in methanol extract. Therefore, although oil and methanol extracts were expected to inhibit both isoenzymes, they activated hCA-I isoenzyme. These results were somewhat surprising. Gallic acid was dominant in the methanol extract in CMS, but the activation or inhibition effect was not necessarily related to that compound since no purified gallic acid was used in the experiments. This effect could be due to the mixing of phenolic compounds. However, given the selective inhibition or activation effect, these findings are very important.

In a study where mineral content was conducted in peel, fruit, and seeds of Cefan melon, it was seen that different the results were obtained from our study. There were some deficiencies in Özbey's (2019) study. For example, the method was not explicitly 
stated in the relevant study. And also results of Özbey (2019) were not explained in detail.

In our study, oil and methanol extracts had different effects on the activities of the two isoenzymes. We believe that this could be caused by the mineral content of the Cefan melon seed extract. For this purpose, elemental content was analyzed by ICP-MS in melon seed extract.

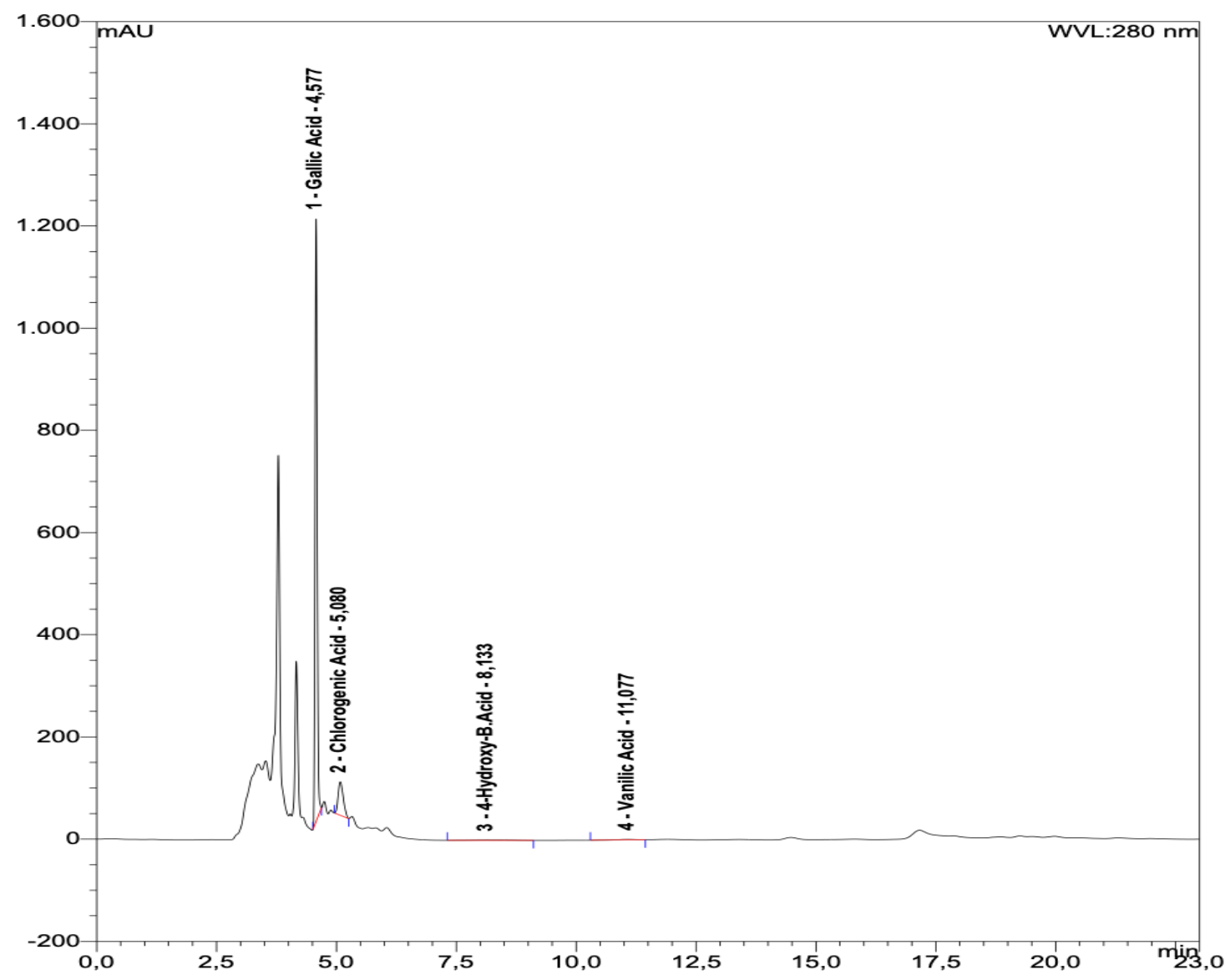

Figure 3. HPLC chromatogram of Cefan melon seed

Mineral content was also analyzed using ICP-MS. The mineral analysis of Cefan melon seeds showed that they were rich in calcium $(6960.59 \pm 220.66 \mathrm{ppm})$, sodium $(4059.93 \pm 80.199 \mathrm{ppm})$, potassium $(1291.18 \pm 44.49 \mathrm{ppm})$ and magnesium $(858.534 \pm 20.173 \mathrm{ppm})$. Moreover, Cefan melon seeds contained low levels of aluminum $(361.247 \pm 10.852 \mathrm{ppm})$, iron $(326.523 \pm 13.409 \mathrm{ppm})$, molybdenum $(278.718 \pm 7.1555 \mathrm{ppm})$, chrome $(143.515 \pm 4.3967 \mathrm{ppm})$ and selenium $(141.241 \pm 14.824 \mathrm{ppm})$ (Table 5). Data obtained in the present study indicated that $48 \%$ of inorganic matter in Cefan melon seed was Ca.

Analysis of Cefan melon seed showed that it contained metals of the $1 \mathrm{~A}$ and $2 \mathrm{~A}$ group as well as the transition metals. It was reported that groups containing free $\mathrm{OH}$ interact with heavy metals and transition metals, whereas those containing benzene ring interact with alkaline and alkaline earth metals (Çalışır, 2014). hCA-I and hCA-II contain about 260 amino acids, but amino acid sequences show only $60 \%$ similarity. (Hassan et al., 2013). In other words, their amino acid sequences are quite different. 
While CA isoenzyme, which has a high number of aromatic amino acids, interacts with alkaline and alkaline earth metals, the isoenzyme which contains a higher amount of amino acids such as serine and threonine interacts with heavy metals and transition metals. Therefore, they may not give the same response to inhibitors and activators.

Table 5. ICP-MS data of melon seed

\begin{tabular}{c|c}
\hline Element & Concentration (ppm) \\
\hline $\mathrm{Ca}$ & $6960.59 \pm 220.66$ \\
$\mathrm{Na}$ & $4059.93 \pm 80.199$ \\
$\mathrm{~K}$ & $1291.18 \pm 44.491$ \\
$\mathrm{Mg}$ & $858.534 \pm 20.173$ \\
$\mathrm{Al}$ & $361.247 \pm 10.852$ \\
$\mathrm{Fe}$ & $326.523 \pm 13.409$ \\
$\mathrm{Mo}$ & $278.718 \pm 7.1555$ \\
$\mathrm{Cr}$ & $143.515 \pm 4.3967$ \\
$\mathrm{Se}$ & $141.241 \pm 14.824$ \\
$\mathrm{Ba}$ & $38.3107 \pm 1.5176$ \\
$\mathrm{Cu}$ & $27.5614 \pm 0.7242$ \\
$\mathrm{~B}$ & $21.1259 \pm 17.028$ \\
$\mathrm{Sr}$ & $13.0292 \pm 0.7815$ \\
$\mathrm{Sb}$ & $5.31247 \pm 0.2819$ \\
$\mathrm{Mn}$ & $2.41853 \pm 0.1566$ \\
$\mathrm{Ni}$ & $1.6246 \pm 0.10619$ \\
\hline
\end{tabular}

\section{Conclusion}

Cefan melon seed is rich in phenolic compounds, unsaturated fatty acids, calcium, sodium, potassium, and magnesium. Thus, Cefan melon seed, which was found to have beneficial in vitro effects, could be useful in different food or cosmetic products because of active substances in it. In addition, extracts can also be used as alternative natural sources for the treatment of different diseases. Our study could be evaluated as a preclinical study. Preclinical studies are needed for clinical studies. Therefore, the present study provides the information needed by many researchers conducting in vivo studies. In the present study, oil and methanol extracts of Cefan melon seed showed different effects on hCA I-II activity. Synthetic drugs involve expensive synthesis and characterization procedures and have many side effects. Therefore, Cefan melon seed may be preferred instead of synthetic drugs in the treatment of diseases such as glaucoma, epilepsy, gastric, neurological disorders, obesity, cancer, and AD. Clinical trials are needed to indicate the potency of a chemical as a drug. Therefore, it would be useful to conduct clinical studies with melon seed extracts for the treatment of the above-mentioned diseases.

Acknowledgments. We thank Siirt University, Science and Technology Application and Research Center, for their contribution. This research received no specific grant from any funding agency in the public, commercial, or not-for-profit sectors.

Conflict of interests. The authors declare that they have no conflict of interests. 


\section{REFERENCES}

[1] Aggarwal, M., Kondeti, B., McKenna, R. (2013): Insights Towards Sulfonamide Drug Specificity in A-Carbonıc Anhydrases. - Bioorganic \& Medicinal Chemistry 21(6): 15261533. Doi: 10.1016/J. Bmc. 2012.08.019.

[2] Akkemik, E., Cicek, B., Camadan, Y., Calisir, U., Onbasioglu, Z. (2018): The determination of the carbonic anhydrase's activators in vitro effect of mixed donor crown ethers. - Journal of Biochemical and Molecular Toxicology 32(3): e22032. https://doi.org/10.1002/jbt.22032.

[3] Bangou, J. M., Kiendrebeogo, M., Compaore, M., Coulibaly, A. Y., Roland Meda, N. T., Abarka Almaraz, N., Zeba, B., Millogo-Rasolodimby, J., Nacoulma, O. G. (2011): Enzyme inhibiting effect and polphenolic content of medicinal plant extracts from Burkina Faso. - Journal of Biological Sciences 11(1): 31-38. DOI: 10.3923/jbs.2011.31.38.

[4] Bentsen, H. (2017): Dietary polyunsaturated fatty acids, brain function and mental health. - Microbial Ecology in Health and Disease 28: 1281916 DOI: http://Dx.Doi.Org/10.1080/16512235.2017.1281916.

[5] Bradford, M. M. (1976): A rapid and sensitive method for the estimation of microgram quantities of protein utilizing the principle of protein-dye binding. - Analytical Biochemistry 72: 248-254. PMID: 942051.

[6] Çalışır, U. (2014): Benzo-tiyo crown eterlerin sentezi ve ekstraktif özelliklerinin incelenmesi. - Balıkesir Üniversitesi, Fen bilimleri Enstitüsü, Kimya ABD, Yüksek Lisans Tezi, Balıkesir.

[7] Cankaya, M., Hernandez, A. M., Ciftci, M., Beydemir, S., Ozdemir, H., Budak, H., Gulcin, I., Comakli, V., Emircupani, T., Ekinci, D., Kuzu, M., Jiang, Q., Eichele, G. and Kufrevioglu, O. I. (2007): An analysis of expression patterns of genes encoding proteins with catalytic activities. - BMC Genomics 8: 232.

[8] Casey, J. R., Sly, W. S., Shah, G. N., Alvarez, B. V. (2009): Bicarbonate homeostasis in excitable tissues: role of $\mathrm{AE} 3 \mathrm{Cl}-\mathrm{HCO} 3-$ exchanger and carbonic anhydrase XIV interaction. - American Journal of Physiology 297(5): C1091-102. DOI: 10.1152/ajpcell.00177.2009.

[9] Chegwidden, W. R., Dodgson, S. J., Spencer, I. M. (2000): The roles of carbonic anhydrase in metabolism, cell growth and cancer in animals. - EXS 90: 343-63 PMID: 11268523.

[10] Cheng, Y., Prusoff, W. H. (1973): Relationship between the inhibition constant (KI) and the concentration of inhibitor which causes 50 per cent inhibition (I50) of an enzymatic reaction. - Biochemical Pharmacology 22(23): 3099-108. DOI: 10.1016/00062952(73)90196-2.

[11] Coleman, J. E. (1975): Chemical reactions of sulfonamides with carbonic anhydrase. Annual Review of Pharmacology 15: 221-242. https://doi.org/10.1146/annurev.pa.15.040175.001253.

[12] Dilek, E. (2017): Activation of two different drugs used in Alzheimer's disease treatment on human carbonic anhydrase isozymes I and II Activity: an in vitro study. - Turk J Pharm Sci 14(2): 164-168. DOI: 10.4274/tjps.43434.

[13] Dodgson, S. J., Forster, R. E. (1985): 2nd. Carbonic anhydrase: inhibition results in decreased urea production by hepatocytes. - J Appl Physiol 60(2): 646-52. DOI: 10.1152/jappl.1986.60.2.646.

[14] Duran, Z. (2014): Malatya ve Elâzı ğ illerinde Yetiştirilen Bazı Üzüm Çeşitlerinin Organik Asit, Seker Ve Fenolik Madde Bileşikleri ile Antioksidan Aktivitelerinin Belirlenmesi. - İnönü Üniversitesi Fen Bilimleri Enstitüsü, Yüksek Lisans Tezi, Gıda Mühendisliği Anabilim Dalı, Malatya, Türkiye.

[15] Durdagi, S., Sentürk, M., Ekinci, D., Balaydin, H. T., Göksu, S., Küfrevioglu, Ö. I., Innocenti, A., Scozzafava, A., Supuran, C. T. (2011): Kinetic and docking studies of 
phenol-based inhibitors of carbonic anhydrase isoforms I, II, IX and XII evidence a new binding mode within the enzyme active site. - Bioorg. Med. Chem. 19: 1381.

[16] El-Hadary, A. E., Ramadan, M. F. (2019): Phenolic profiles, antihyperglycemic, antihyperlipidemic, and antioxidant properties of pomegranate (Punica granatum) peel extract. - Journal of Food Biochemistry e12803. https://doi. org/10.1111/jfbc.12803.

[17] FAOSTAT (2018): Production quantities of melons, other (inc.cantaloupes) by country average 1994-2017. - http://www.fao.org/faostat/en/\#data/QC/visualize.05.02.2018-21: 18.

[18] Gay, C. V., Schraer, H., Anderson, R. E., Cao, H. (1984): Current studies on the location and function of carbonic anhydrase in osteoclasts. - Annals of the New York Academy of Sciences 429: 473-8. PMID: 6430184.

[19] Hassan, M. I., Shajee, B., Waheed, A., Ahmad, F., Sly, W. S. (2013): Structure, function and applications of carbonic anhydrase isozymes. - Bioorganic \& Medicinal Chemistry 21(6): 1570-1582. DOI: 10.1016/j.bmc.2012.04.044.

[20] Kale, S. (2017): Farklı Kavun Çeşitlerinin Bazı Fizikokimyasal Özelliklerinin Belirlenmesi. - Selçuk Üniversitesi, Fen Bilimleri Enstitüsü, Gıda Mühendisliği Ana Bilim Dalı, Yüksek Lisans Tezi, Konya, Türkiye.

[21] Karaçelik, A. A. (2018): Effect of carbonic anhydrase activity of the herbal tea components and food additives. - Karadeniz Teknik Üniversitesi, Fen Bilimleri Enstitüsü, Kimya Anabilim Dalı, Biyokimya Bilim Dalı, Yüksek Lisans Tezi, Trabzon, Türkiye.

[22] Kılıçoğlu, F. M. (2018): Güneydoğu Anadolu Bölgesinde Yetişen Farklı Nıcotıana Spp. Tiplerinin Yă Asidi, Fenolik Flavonoid Ve Nikotin İçeriklerinin Belirlenerek Kemometrik Yönden İncelenmesi. - Batman Üniversitesi, Fen Bilimleri Enstitüsü, Biyoloji Anabilim Dalı, Yüksek Lisans Tezi, Batman, Türkiye.

[23] Kuru, R., Yilmaz, S., Tasli, N, P., Yarat, A., Sahin, F. (2019): Boron content of some foods consumed in Istanbul, Turkey. - Biol Trace Elem Res 187: 1. https://doi.org/10.1007/s12011-018-1319-9.

[24] Laemmli, U. K. (1970): Cleavage of structural proteins during the assembly of the head of bacteriophage T4. - Nature 227: 680-685 PMID: 5432063.

[25] Lee, H., Park, J. W. (2014): Unsaturated fatty acids, desaturases, and human health. Journal of Medicinal Food 17(2): 189-197. DOI: 10.1089/jmf.2013.2917.

[26] Lehtonen, J., Shen, B., Vihinen, M., Casini, A., Scozzafava, A., Supuran, C. T., Parkkila, A. K., Saarnio, J., Kivelä, A. J., Waheed, A., Sly, W. S., Parkkila. S. (2004): Characterization of CA XIII, a novel member of the carbonic anhydrase isozyme family. - The Journal of Biological Chemistry 279(4): 2719-27. DOI: 10.1074/jbc.M308984200.

[27] Liperoti, R., Landi, F., Fusco, O., Bernabei, R., Onder, G. (2009): Omega-3 polyunsaturated fatty acids and depression: a review of the evidence. - Current Pharmaceutical Design 15: 4165-4172. DOI: 10.2174/138161209789909683.

[28] Malićanin, M., Rac, V., Antic, V., Antić, M., Palade, M., Kefalas, P., Rakic, V. (2014): Content of antioxidants, antioxidant capacity and oxidative stability of grape seed oil obtained by ultrasound assisted extraction. - JAOCS, Journal of the American Oil Chemists' Society 91. 989-999. 10.1007/s11746-014-2441-2.

[29] Mehra, M., Pasricha, V., Gupta, RK. (2015): Estimation of nutritional, phytochemical and antioxidant activity of seeds of musk melon (Cucumis melo) and watermelon (Citrullus lanatus) and nutritional analysis of their respective oils. - Journal of Pharmacognosy and Phytochemistry 3(6): 98-102.

[30] Mello, M. L. S., Bora, P. S., Narendra, N. (2001): Fatty and amino acids composition of melon (Cucumis melo Var. saccharinus) seeds. - Journal of Food Composition and Analysis 14: 69-74. DOI: 10.1006/jfca.2000.0952.

[31] Montealegre, R. R., Peces, R. R., Vozmediano, J. L. C., Gascuena, J. M., Romero, E. G. (2006): Phenolic compounds in skin and seeds in ten grape Vitis vinifera varieties grown 
in a warm climate. - Journal of Agricultural and Food Chemistry 19: 687-693. DOI: 10.3390/ijms13033492.

[32] Nishimori, I., Innocenti, A., Vullo, D., Scozzafava, A., Supuran, C. T. (2007): Carbonic anhydrase inhibitors. Inhibition studies of the human secretory isoform VI with anions. Bioorg Med Chem Lett. 17(4): 1037-42. DOI: 10.1016/j.bmcl.2006.11.028.

[33] Nyam, K. L., Tan, C. P., Man, Y. B. C., Lai, O. M., Long, K. (2009): Physicochemical properties of Kalahari melon seed oil following extractions using solvent and aqueous enzymatic methods. - International Journal of Food Science and Technology 44: 694701. https://doi.org/10.1111/j.1365-2621.2008.01828.x.

[34] Oluba, O., Adeyemi, O., Ojieh, G., Isiosio, I. (2007): Fatty acid composition of Citrullus lanatus (Egusi melon) oil and its effect on serum lipids and some serum enzymes. - The Internet Journal of Cardiovascular Research 5(2): 1-7.

[35] Özbek, A. (2019): Siirt İlinde Yetiştirilen "Cefan” Kavunu'nun (Cucumis Melo L. C. V./Cucurbitaceae) Bazı Biyokimyasal Özelliklerinin Belirlenmesi. - Van Yüzüncü Yıl Üniversitesi, Fen Bilimleri Enstitüsü, Biyoloji Anabilim Dalı, Yüksek Lisans Tezi, Van, Türkiye.

[36] Picaud, S. S., Muniz, J. R., Kramm, A., Pilka, E. S., Kochan, G., Oppermann, U., Yue, W. W. (2009): Crystal structure of human carbonic anhydrase-related protein VIII reveals the basis for catalytic silencing. - Proteins 76(2): 507-11. DOI: 10.1002/prot.22411.

[37] Ramakrishna, G., Viswanadnam, R. K. S., Rao, T. (1970): Pilot plant oil production from muskmelon. - Oil Mill Gazette 75: 8.

[38] Rolim, P. M., Fidelis, G. P., Padilha, C. E. A., Santos, E. S., Rocha, H. A. O., Macedo, G. R. (2018): Phenolic profile and antioxidant activity from peels and seeds of melon (Cucumis melo L. var. reticulatus) and their antiproliferative effect in cancer cells. Brazilian Journal of Medical and Biological Research 51(4): e6069. DOI: 10.1590/1414$431 X 20176069$.

[39] Sacan, O., Yildiz, E. (2014): Turhan, lipoxygenase inhibitory activities of some plant extracts and chemical compounds. - The Journal of Biological Chemistry 73(2): 47-52.

[40] Scozzafava, A., Mastrolorenzo, A., Supuran, C. T. (2006): Carbonic anhydrase inhibitors and activators and their use in therapy. - Expert Opinion on Therapeutic Patents 16(12): 1627-1664. https://doi.org/10.1517/13543776.16.12.1627.

[41] Sevim, O. (2018): Determination of some macro and micro element contents of multimedical plants growed in agri and the effects of these elements on metabolic enzyme. Ağrı İbrahim Çeçen Üniversitesi, Fen Bilimleri Enstitüsü, Kimya Anabilim Dalı, Yüksek Lisans Tezi, Ağrı, Türkiye.

[42] Supuran, C. T. (2008): Carbonic anhydrases as drug targets. - Current Pharmaceutical Design 14(7): 601-2. DOI:10.2174/138161208783877910.

[43] Teotia, M. S., Ramakrishna, P. (1984): Chemistry and technology of melon seeds. Journal of Food Science and Technology 21: 332-340.

[44] Torring, M. S., Holmgaard, K., Hessellund, A., Aalkjaer, C., Bek, T. (2009): The vasodilating effect of acetazolamide and dorzolamide involves mechanisms other than carbonic anhydrase inhibition. - Investigative Ophthalmology \& Visual Science 50(1): 345-51. DOI: 10.1167/iovs.08-2435.

[45] Uymaz, Y. (2017): Karbonik Anhidraz Enziminin Afinite Kromatografisiyle Saflaştırılması Ve Biyoteknolojik Uygulamaları. - Eskişehir Anadolu Üniversitesi, Fen Bilimleri Enstitüsü, Eskişehir.

[46] Van Wyk, B. E., Gericke, N. (2000): People's Plants. A Guide to Useful Plants of South Africa. - Briza Publications, Pretoria.

[47] Verporte, J. A., Mehta, S., Edsall, J. T. (1967): Esterase activities of human carbonic anhydrases B and C. - The Journal of Biological Chemistry 242(422): 1-9.

[48] Woolley, P. (1975): Models for metal ion function in carbonic anhydrase. - Nature 258(5537): 677-82. 
[49] Xu, C., Zhang, Y., Cao, L., Lu, J. (2010): Phenolic compounds and antioxidant properties of different grape cultivars grown in China. - Food Chemistry 119: 1557-1565. 10.1016/j.foodchem.2009.09.042.

[50] Yurtvermez, B. (2016): Isolation of bioactive secondary metabolites from tarragon (Artemisia dracunculus L.) and identification of their chemical structures. - Ağrı İbrahim Çeçen Üniversitesi, Fen Bilimleri Enstitüsü, Kimya Anabilim Dalı, Yüksek Lisans Tezi, Ağrı, Türkiye.

[51] Zeb, A. (2016): Phenolic profile and antioxidant activity of melon (Cucumis melo L.) seeds from Pakistan. - Foods 5: 67. DOI: 10.3390/foods5040067. 